\title{
PERGAMON
}

www.elsevier.com/locate/watres

\section{FLUORIDE REMOVAL IN A FIXED BED PACKED WITH GRANULAR CALCITE}

\author{
MIN YANG ${ }^{1 * M}$, TAKAYUKI HASHIMOTO ${ }^{2}$, NOBUYUKI HOSHI ${ }^{2}$ and \\ HARUKI MYOGA ${ }^{2}$
}

\begin{abstract}
${ }^{1}$ State Key Laboratory of Environmental Aquatic Chemistry, Research Center for Eco-Environmental Sciences, P.O. Box 2871, Beijing 100085, People's Republic of China and ${ }^{2}$ Central Research Laboratories, Organo Corporation, 4-9, Kawagishi 1-Chome, Toda City, Saitama Pref. 335-0015, Japan
\end{abstract}

(First received 1 August 1998; accepted in revised form 1 December 1998)

\begin{abstract}
A fixed bed reactor filled with calcite particles (mean strokes diameter, $0.20 \mathrm{~mm}$ ) was constructed and the reactor was used to treat synthetic wastewater containing $\mathrm{HF}, \mathrm{NaF}, \mathrm{NH}_{4} \mathrm{~F}$ or $\mathrm{Na}_{2} \mathrm{SiF}_{6}$ under various conditions. Calcium ions $\left(\mathrm{Ca}^{2+}\right)$ were found to exist in the treated effluent and the molar $\mathrm{Ca}^{2+}$ concentration $\left(\left[\mathrm{Ca}^{2+}\right]\right)$ was related to the molar ratio of $\mathrm{H}^{+}$to $\mathrm{F}^{-}\left(\left[\mathrm{H}^{+}\right]_{0} /\left[\mathrm{F}^{-}\right]_{0}\right)$ in influent as $\log _{10}\left[\mathrm{Ca}^{2+}\right]=0.020\left[\mathrm{H}^{+}\right]_{0} /\left[\mathrm{F}^{-}\right]_{0}-4.24$. The effluent $\mathrm{F}^{-}$concentration was determined by the concentration of effluent $\mathrm{Ca}^{2+}$ as $\left[\mathrm{F}^{-}\right]^{2}\left[\mathrm{Ca}^{2+}\right]^{0.94}=3.98 \times 10^{-10}$ under an $\mathrm{SV}$ of 1.0 to $5.0 \mathrm{~h}^{-1}$ and $25^{\circ} \mathrm{C}$. This equation was similar with that of the solubility product of $\mathrm{CaF}_{2}$ and could be applied to wastewaters containing $\mathrm{HF}, \mathrm{NaF}, \mathrm{NH}_{4} \mathrm{~F}$ or $\mathrm{Na}_{2} \mathrm{SiF}_{6}$ under an influent $\mathrm{F}^{-}$concentration ranging from 25 to $3000 \mathrm{mg} \mathrm{l}^{-1}$. The effluent $\mathrm{F}^{-}$was also found to be related to effluent $\mathrm{pH}$ as $\log _{10}\left[\mathrm{~F}^{-}\right]=0.51 \mathrm{pH}-2.91$. The effluent $\mathrm{F}^{-}$was about $6 \mathrm{mg} \mathrm{l}^{-1}$ at an effluent $\mathrm{Ca}^{2+}$ of $80 \mathrm{mg} \mathrm{l}^{-1}$ or effluent $\mathrm{pH}$ of 6.8 under the above conditions. The effluent $\mathrm{F}^{-}$increased from 6 to $12 \mathrm{mg}^{-1}$ and effective calcite conversion rate decreased from $c a$. 60 to $40 \%$ when SV was increased from 1.6 to $16.0 \mathrm{~h}^{-1}$ at a $\left[\mathrm{H}^{+}\right]_{0} /\left[\mathrm{F}^{-}\right]_{0}$ of 0.75 . Significant increase of effluent $\mathrm{F}^{-}$as well as decrease of effective calcite conversion rate was observed when reaction temperature was decreased to $8.5^{\circ} \mathrm{C}$ at an $\mathrm{SV}$ of $7 \mathrm{~h}^{-1}$ and $\left[\mathrm{H}^{+}\right]_{0} /\left[\mathrm{F}^{-}\right]_{0}$ of 0.75 . The performance of the reactor was affected by the existence of $\mathrm{SO}_{4}^{2-}$ to some extent and significantly inhibited by $\mathrm{PO}_{4}^{3-}$. A molar ratio of $\mathrm{PO}_{4}^{3-}$ to $\mathrm{F}^{-}$higher than 0.05 stopped $\mathrm{F}^{-}$removal at a $\mathrm{PO}_{4}^{3-}$ of $15 \mathrm{mg}^{-1}$. (C) 1999 Elsevier Science Ltd. All rights reserved
\end{abstract}

Key words - fluoride removal, calcite, replacement, wastewater treatment

\section{INTRODUCTION}

Hydrofluoric acid (HF) and ammonium fluoride $\left(\mathrm{NH}_{4} \mathrm{~F}\right)$ are the essential chemicals for wet processes of LSI (large-scale integration) and LCD (liquid crystal display) production lines. These fluorine compounds $(\mathrm{F})$ have been removed from wastewater by using a calcium fluoride $\left(\mathrm{CaF}_{2}\right)$ precipitation reaction followed by a solid-liquid separation process for several decades. The $\mathrm{CaF}_{2}$ precipitates are usually so fine that they can only be separated from the treated liquid in sedimentation tanks by adding inorganic coagulants like aluminum sulfate $\left(\mathrm{Al}_{2}\left(\mathrm{SO}_{4}\right)_{3}\right)$ or polyaluminum chloride (PAC) to help form flocs. In most cases, the effluent $\mathrm{F}^{-}$remains as high as 15 to $30 \mathrm{mg} \mathrm{l}^{-1}$ after $\mathrm{CaF}_{2}$ precipitation even under a relatively high remaining

*Author to whom all correspondence should be addressed. [Tel.: +86-10-62923475; fax: + 86-10-62923475; e-mail: yang-hu@263.net].
$\mathrm{Ca}^{2+}$ concentration (Eto and Takadoi, 1978). Therefore, the above coagulants have been used not only for the purpose of removing the fine $\mathrm{CaF}_{2}$ particles, but also for the purpose of adsorbing the remaining $\mathrm{F}^{-}$in the treated effluent. So, the coagulants are usually used in a very high dose, which results in the increase of sludge and makes the precipitation slurry difficult to dewater.

An alternative process, which utilizes the reaction of $\mathrm{F}^{-}$-bearing wastewaters with calcite particles, has been proposed since the 1970's (Augustyn et al., 1978; Simonsson, 1979; Ekdunge and Simonsson, 1984). The reaction is usually expressed as equation (1) and the equilibrium constant $K$ was calculated from the solubility products of calcite and fluorite (Simonsson, 1979). This has been considered to be a pseudomorphic replacement involving epitaxial growth of the (110) plane of fluorite in the (1011) plane of calcite, leaving the $\mathrm{Ca}^{2+}$ positions nearly unchanged (Glover and Sippel, 1962). The molecular volume of $\mathrm{CaF}_{2}$ in fluorite is $33 \%$ smaller than 
that of $\mathrm{CaCO}_{3}$ in calcite, so the replacement reaction leaves $33 \%$ additional porosity in fluorite, which facilitates the diffusion of $\mathrm{F}^{-}$ions into and of $\mathrm{CO}_{3}^{2-}$ ions out of the particles (Trautz et al., 1961).

$$
2 \mathrm{~F}^{-}+\mathrm{CaCO}_{3}(\mathrm{~s})=\mathrm{CaF}_{2}(\mathrm{~s})+\mathrm{CO}_{3}^{2-} \quad K_{1}=200
$$

This calcite process was initially applied to the treatment of $\mathrm{NH}_{4} \mathrm{~F}$ solution from the AUC process for conversion of $\mathrm{UF}_{6}$ to $\mathrm{UO}_{2}$ (Simonsson, 1979). Recently, efforts have been made to apply it to the treatment of high strength $\mathrm{HF}$ and buffered hydrofluoric acid (BHF, a mixture of $\mathrm{HF}$ and $\mathrm{NH}_{4} \mathrm{~F}$ ) wastewater (Sato et al., 1995; Miki et al., 1996; Sato, 1997). However, the applications have been mainly limited to the purpose of sludge reduction and fluoride recovery through $\mathrm{CaF}_{2}$ formation and the treated effluent needs to be treated further by using a conventional process to satisfy wastewater discharge criteria (below 5 to $15 \mathrm{mg} \mathrm{l}^{-1}$ in Japan, varying according to autonomies). While recovery of $\mathrm{CaF}_{2}$ from the high strength wastewater is of considerable significance from the viewpoint of recycling resource, the problems for treating low to medium strength wastewater remain to be unresolved. Furthermore, since low strength wastewater is more difficult to be treated by the conventional process (Majima and Takatsuki, 1987), the effluent from the calcite process poses new problems for $\mathrm{F}^{-}$ removal. Ekdunge and Simonsson (1984) have found that a semicontinuous fixed bed of limestone particles could reduce the $\mathrm{F}^{-}$content of $\mathrm{NH}_{4} \mathrm{~F}$ solution to $10-20 \mathrm{mg} \mathrm{l}^{-1}$ at $30^{\circ} \mathrm{C}$ in a series of three columns. Although the result has demonstrated the possibility of the calcite process for wider applications, multistep treatment as well as the need for removing $\mathrm{CO}_{2}$ and $\mathrm{NH}_{3}$ from treated water of the first column would become a heavy burden for wastewater treatment. Furthermore, a proper process control strategy is still not available since a quantitative relationship between the effluent $\mathrm{F}^{-}$ concentration and a controllable parameter has not

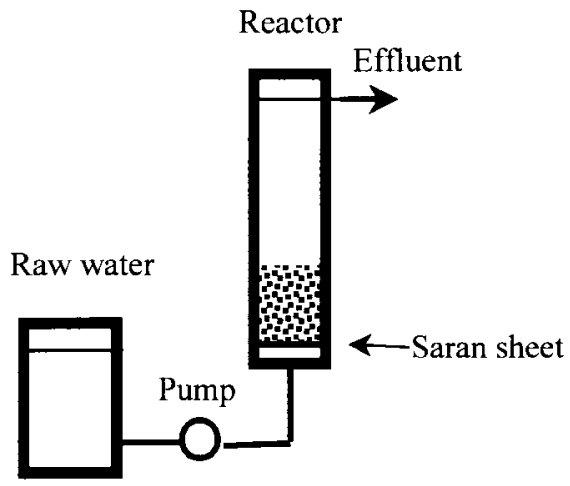

Fig. 1. Schematic diagram of calcite reactor. yet been elucidated, which has also largely prevented the calcite process from wider application.

In this study, a fixed bed reactor filled with calcite particles was constructed and performance of the reactor was evaluated on treating synthetic wastewater containing $\mathrm{HF}, \mathrm{NaF}, \mathrm{NH}_{4} \mathrm{~F}$ or $\mathrm{Na}_{2} \mathrm{SiF}_{6}$ under various conditions. The study was focused on elucidating relations between effluent $\mathrm{F}^{-}$and some controllable parameters in order to establish a process control strategy. The effects of SV (space velocity), temperature and the existence of $\mathrm{SO}_{4}^{2-}$ and $\mathrm{PO}_{4}^{3-}$ on $\mathrm{F}^{-}$removal were also investigated.

\section{MATERIAL AND METHODS}

A polyacrylic resin column, with an inner diameter of $26 \mathrm{~mm}$ and effective height of $600 \mathrm{~mm}$, was used as the fixed bed reactor (Fig. 1). In each batch of experiment, $200 \mathrm{~g}$ calcite of a given particle distribution (Table 1) was packed on the saran sheet spread in the lower part of the reactor, giving a fixed-bed volume of $140 \mathrm{~cm}^{3}$. Synthetic wastewater, which was prepared by dissolving $\mathrm{NaF}$, $\mathrm{NaSiF}_{6}, \mathrm{HF}$ or $\mathrm{NH}_{4} \mathrm{~F}$ into pure water and then adjusting the $\mathrm{H}^{+}$to $\mathrm{F}^{-}$molar ratio to given values with $\mathrm{NaOH}$ or $\mathrm{HCl}$, was pumped into the bottom of the reactor. Reaction temperature was controlled at $25^{\circ} \mathrm{C}$ except for specified conditions by immersing reaction part of the reactor into a water bath. Concentrations of $\mathrm{F}^{-}$and $\mathrm{Ca}^{2+}$ were respectively determined on two ionselective electrode meters (IM-40S, TOA Electric Waves Co., Japan). It should be noted that $\mathrm{Na}_{2} \mathrm{SiF}_{6}-\mathrm{F}$ could also be measured on the fluoride ion-selective electrode meter operated at a $\mathrm{pH}$ of 5.2. It was possible that the fluoride ion-selective electrode responded to the fluoride ions dissociated from $\mathrm{Na}_{2} \mathrm{SiF}_{6}$ at the measuring $\mathrm{pH}$ through equation (2) (Mooney et al., 1982; Ohmi, 1995). Concentrations of $\mathrm{SO}_{4}^{2-}$ and $\mathrm{PO}_{4}^{3-}$ were measured on ion-chromatograph (IC-7000, Yokogawa Instruments Co., Japan).

$$
\mathrm{SiF}_{6}^{2-}+2 \mathrm{H}_{2} \mathrm{O}=6 \mathrm{~F}^{-}+4 \mathrm{H}^{+}+\mathrm{SiO}_{2}
$$

\section{RESULTS AND DISCUSSION}

\section{Characteristics of calcite treatment process}

In a conventional $\mathrm{F}^{-}$removal process, $\mathrm{Ca}^{2+}$ ions are added into the wastewater to create $\mathrm{CaF}_{2}$ precipitate and the remaining $\mathrm{F}^{-}$concentration is mainly determined by the remaining $\mathrm{Ca}^{2+}$ concentration according to the solubility product of fluorite as shown in equation (3). While the calcite treatment process has been considered to be the result of replacement of calcite by fluorite (Glover and Sippel, 1962), the fact that $\mathrm{F}^{-}$is also removed through formation of $\mathrm{CaF}_{2}$ indicated that this process is possibly the same as the conventional one in nature. The difference is that $\mathrm{Ca}^{2+}$ ions are obtained through substituting carbonate ions $\left(\mathrm{CO}_{3}^{2+}\right)$ from calcite by $\mathrm{F}^{-}$in the case of the calcite process equation (1). Although $\mathrm{Ca}^{2+}$ is not added from outside, it is possible that some $\mathrm{Ca}^{2+}$ ions are released into the solution during replacement, and the remaining $\mathrm{F}^{-}$concentration is related to the 
Table 1. Physical and chemical properties of the calcite

\begin{tabular}{lccccc}
\hline & Physical properties & & & \multicolumn{2}{c}{ Chemical composition } \\
\hline Particle distribution & $>35$ mesh & $<1 \%$ & $\mathrm{CaCO}_{3}$ & $\%$ & 99.0 \\
& $35-70$ mesh & $75-95 \%$ & $\mathrm{SiO}_{2}$ & $\%$ & 0.1 \\
& $<70$ mesh & $<10 \%$ & $\mathrm{Al}_{2} \mathrm{O}_{3}$ & $\%$ & 0.05 \\
Strokes diameter & $\mathrm{mm}$ & 0.205 & $\mathrm{Fe}_{2} \mathrm{O}_{3}$ & $\%$ & 0.01 \\
Density & $\mathrm{g} \mathrm{cm}^{-3}$ & 2.7 & $\mathrm{MgO}$ & $\%$ & 0.15 \\
Apparent density & $\mathrm{g} \mathrm{cm}^{-3}$ & 1.35 & $\mathrm{P}$ & $\%$ & 0.001 \\
\hline
\end{tabular}

$\mathrm{Ca}^{2+}$ concentration according to equation (3). Since $\mathrm{H}^{+}$is an important factor on $\mathrm{Ca}^{2+}$ dissolution, molar ratio of initial $\mathrm{H}^{+}$to $\mathrm{F}^{-}\left(\left[\mathrm{H}^{+}\right]_{0} /\left[\mathrm{F}^{-}\right]_{0}\right)$ was varied from 0 to $125 \%$ under the following conditions: space volume (SV), 1.0 to $5.0 \mathrm{~h}^{-1}$; influent $\mathrm{F}^{-}, 25$ to $3000 \mathrm{mg} \mathrm{l}^{-1}$. $\mathrm{NaF}, \mathrm{NH}_{4} \mathrm{~F}, \mathrm{HF}$ and $\mathrm{Na}_{2} \mathrm{SiF}_{6}$ were used as $\mathrm{F}$ sources, respectively, and the $\mathrm{Na}_{2} \mathrm{SiF}_{6}-\mathrm{F}$ was also expressed as $\mathrm{F}^{-}$in this study since it was found that the $\mathrm{F}$ concentration of the $\mathrm{Na}_{2} \mathrm{SiF}_{6}$ solution could be measured on the fluoride ion-selective electrode meter.

$$
\begin{aligned}
2 \mathrm{~F}^{-}+ & \mathrm{Ca}^{2+} \rightarrow \mathrm{CaF}_{2} \\
& K_{\text {sp }}=\left[\mathrm{F}^{-}\right]^{2}\left[\mathrm{Ca}^{2+}\right]=3.5 \times 10^{-11}
\end{aligned}
$$

Figure 2 shows the effects of the initial $\mathrm{H}^{+} / \mathrm{F}^{-}$ ratio on effluent $\mathrm{Ca}^{2+}$ and Fig. 3 shows the relationship between effluent $\mathrm{Ca}^{2+}$ and $\mathrm{F}^{-}$. Figure 2 indicates that dissolution of $\mathrm{Ca}^{2+}$ from calcite occurred during the replacement reaction. While a scattering of data at $\left[\mathrm{H}^{+}\right]_{0} /\left[\mathrm{F}^{-}\right]_{0}$ lower than $30 \%$ was observed, the logarithm of effluent $\mathrm{Ca}^{2+}$ concentration was found to be almost linearly related to $\left[\mathrm{H}^{+}\right]_{0} /\left[\mathrm{F}^{-}\right]_{0}$, and the relation did not change with variation of $\mathrm{F}$ source. The relation between $\left[\mathrm{H}^{+}\right]_{0} /\left[\mathrm{F}^{-}\right]_{0}$ and molar concentration of effluent $\mathrm{Ca}^{2+}\left(\left[\mathrm{Ca}^{2+}\right]\right)$ was established as equation (5) based on Fig. 2. It is interesting that the effluent $\mathrm{Ca}^{2+}$ was determined by the molar ratio of $\mathrm{H}^{+}$to $\mathrm{F}^{-}$, which indicated the essential difference between

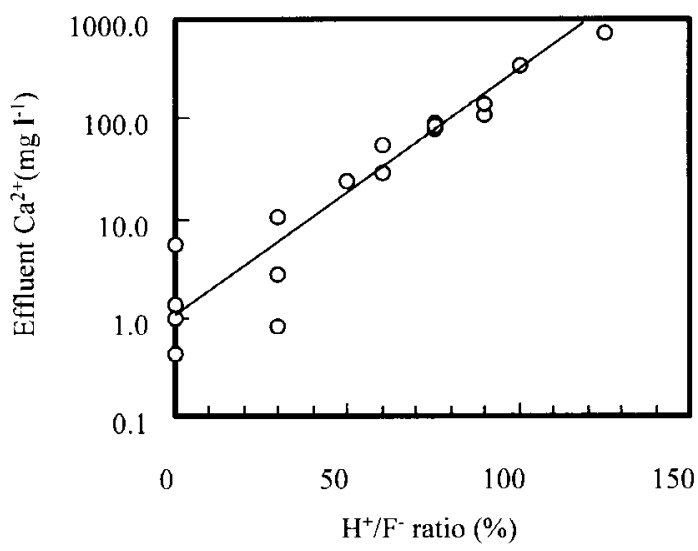

Fig. 2. Effects of $\mathrm{H}^{+} / \mathrm{F}^{-}$ratio on effluent $\mathrm{Ca}^{2+}$. SV, 1$5 \mathrm{~h}^{-1} ; \mathrm{F}$ sources, $\mathrm{NaF}, \mathrm{NH}_{4} \mathrm{~F}, \mathrm{HF}$ or $\mathrm{Na}_{2} \mathrm{SiF}_{6} ; \mathrm{F}^{-}, 25$ to $3000 \mathrm{mg} \mathrm{l}^{-1}$. the replacement by HF and calcite dissolution by the other acids as shown in equation (4). When calcite particles are put into an $\mathrm{HCl}$ or $\mathrm{H}_{2} \mathrm{SO}_{4}$ solution, the extent of dissolution is mainly determined by the concentration of the acid, i.e. the concentration of $\mathrm{H}^{+}$, and the ratio of $\mathrm{H}^{+}$to $\mathrm{Cl}^{-}$ or $\mathrm{SO}_{4}^{2-}$ does not have much meaning. Figure 3 shows that similar with the conventional $\mathrm{CaF}_{2}$ precipitation reaction, the effluent $\mathrm{F}^{-}$concentration depended on the effluent $\mathrm{Ca}^{2+}$ concentration in the fixed bed calcite process. It was not necessary to raise reaction temperature or strip $\mathrm{NH}_{3}$ in order to obtain a high $\mathrm{F}^{-}$removal. An effluent $\mathrm{F}^{-}$of below $10 \mathrm{mg}^{-1}$ could be obtained by adjusting the $\left[\mathrm{H}^{+}\right]_{0} /$ $\left[\mathrm{F}^{-}\right]_{0}$ of wastewater to give an effluent $\mathrm{Ca}^{2+}$ of more than $50 \mathrm{mg}^{-1}$ at $25^{\circ} \mathrm{C}$. Difference of $\mathrm{F}$ sources did not affect the relation between the effluent $\mathrm{F}^{-}$and $\mathrm{Ca}^{2+}$, which could be expressed as equation (6) (at $\left[\mathrm{Ca}^{2+}\right]>0.05 \mathrm{mM}$ ), over the whole influent $\mathrm{F}^{-}$range from 25 to $3000 \mathrm{mg} \mathrm{l}^{-1}$. Equation (7) can be obtained by rewriting equation (6). It was clear that equation (7) was very similar to the $K_{\text {sp }}$ of $\mathrm{CaF}_{2}$ in equation (3), which is also plotted in Fig. 3 for comparison. The order of 0.94 for $\left[\mathrm{Ca}^{2+}\right]$ in equation (7) was perhaps mainly originated from experimental error. The difference of one order between $\left[\mathrm{F}^{-}\right]^{2}\left[\mathrm{Ca}^{2+}\right]^{0.94}\left(3.98 \times 10^{-10}\right)$ and $K_{\mathrm{sp}}$ $\left(3.46 \times 10^{-11}\right)$ was perhaps because complete equilibrium was not achieved at an SV of $1.0 \mathrm{~h}^{-1}$ or higher.

$$
\mathrm{H}^{+}+\mathrm{CaCO}_{3} \rightarrow \mathrm{HCO}_{3}^{-}+\mathrm{Ca}^{2+}
$$

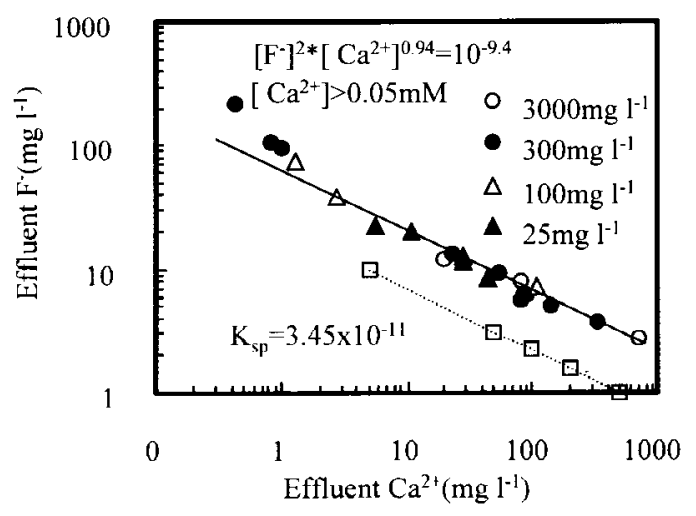

Fig. 3. Effects on effluent $\mathrm{Ca}^{2+}$ on $\mathrm{F}^{-}$removal. SV, $1-$ $5 \mathrm{~h}^{-1}$; F sources, $\mathrm{NaF}, \mathrm{NH}_{4} \mathrm{~F}, \mathrm{HF}$ or $\mathrm{Na}_{2} \mathrm{SiF}_{6}$. 


$$
\begin{gathered}
\log _{10}\left[\mathrm{Ca}^{2+}\right]=0.020\left[\mathrm{H}^{+}\right]_{0} /\left[\mathrm{F}^{-}\right]_{0}-4.24 \\
\log _{10}\left[\mathrm{~F}^{-}\right]=-0.47 \log _{10}\left[\mathrm{Ca}^{2+}\right]-4.70 \\
{\left[\mathrm{~F}^{-}\right]^{2}\left[\mathrm{Ca}^{2+}\right]^{0.94} \fallingdotseq\left[\mathrm{F}^{-}\right]^{2}\left[\mathrm{Ca}^{2+}\right]=3.98 \times 10^{-10}}
\end{gathered}
$$

For $\mathrm{CaF}_{2}$ precipitation, supersaturation of $\mathrm{F}^{-}$ and $\mathrm{Ca}^{2+}$ is the major premise. According to equation (3), two $\mathrm{F}^{-}$react with one $\mathrm{Ca}^{2+}$ and the ion product of the reaction can be expressed as $\left[\mathrm{F}^{-}\right]^{2}\left[\mathrm{Ca}^{2+}\right]$. The ion product equation indicates that it is much easier to achieve a supersaturation state at a high initial $\mathrm{F}^{-}$concentration. So, $\mathrm{F}^{-}$ removal performance of a conventional process not only depends on $\mathrm{Ca}^{2+}$ doses, but also is largely affected by the initial $\mathrm{F}^{-}$concentration, which is why low strength wastewater is difficult to be treated. For wastewater containing $\mathrm{F}^{-}$lower than $50 \mathrm{mg} \mathrm{l}^{-1}$, it is almost impossible to directly remove $\mathrm{F}^{-}$through $\mathrm{CaF}_{2}$ precipitation with a reasonable $\mathrm{Ca}^{2+}$ dose (Majima and Takatsuki, 1987).

However, as shown in Fig. 3, $\mathrm{F}^{-}$removal performance of the calcite process was not affected by variations of influent $\mathrm{F}^{-}$over the whole $\mathrm{F}^{-}$range of 25 to $3000 \mathrm{mg} \mathrm{l}^{-1}$, which could be considered to be an important advantage over the conventional method. One of the factors possibly contributing to this result was the continuous dissolution of $\mathrm{Ca}^{2+}$ ions from calcite particles. Although the bulk $\mathrm{Ca}^{2+}$ concentration was not so high, it was possible that there existed high $\mathrm{Ca}^{2+}$ concentration zones around and inside calcite particles during the replacement reaction. The $\mathrm{Ca}^{2+}$ concentrations in the locally existing high concentration zones were possibly so high that the influence of the influent $\mathrm{F}^{-}$concentration could be offset. Fluorite formed on the surface of the calcite particles provided numerous crystal seeds for succeeding $\mathrm{F}^{-}$to crystallize with $\mathrm{Ca}^{2+}$, which could not be expected from a conventional system since $\mathrm{CaF}_{2}$ grains formed during treatment will be washed out of the reactor.

In electronic industry, most of $\mathrm{HF}$ and $\mathrm{BHF}$ are used for etching and washing silicone wafers, and $\mathrm{SiF}_{6}^{2-}$ is formed via equations (8) and (9) (Ohmi, 1995). $\mathrm{SiF}_{6}^{2-}$ has been considered to be difficult to be removed by the conventional method. In this study, however, $\mathrm{Na}_{2} \mathrm{SiF}_{6}-\mathrm{F}$ was effectively removed in the fixed bed reactor. This result was also possibly originated from the existence of high $\mathrm{Ca}^{2+}$ concentration zones.

$$
\begin{gathered}
\mathrm{SiO}_{2}+2 \mathrm{HF}_{2}^{-}+2 \mathrm{H}_{3} \mathrm{O}^{+}=\mathrm{SiF}_{4}+4 \mathrm{H}_{2} \mathrm{O} \\
\mathrm{SiF}_{4}+2 \mathrm{HF}=\mathrm{H}_{2} \mathrm{SiF}_{6}
\end{gathered}
$$

When F-bearing wastewater with a certain $\left[\mathrm{H}^{+}\right]_{0} /$ $\left[\mathrm{F}^{-}\right]_{0}$ was passed through the fixed bed reactor, most of $\mathrm{F}^{-}$ions were removed from wastewater to

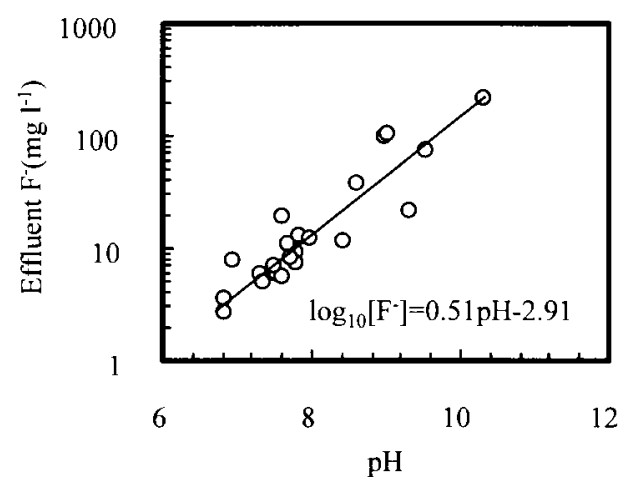

Fig. 4. Relation between effluent $\mathrm{pH}$ and $\mathrm{F}^{-}$. For conditions, see Fig. 3.

form $\mathrm{CaF}_{2}$, leaving $\mathrm{H}^{+}$ions in the solution. $\mathrm{H}^{+}$ ions will react with $\mathrm{CO}_{3}^{2-}$ ions replaced by $\mathrm{F}^{-}$ions as shown in equations (10) and (11) (Cordell, 1968). It is apparent that the effluent $\mathrm{pH}$ will be mainly determined by equilibrium of equations (10) and (11). Therefore, it could be estimated that there also existed a certain relation between effluent $\mathrm{F}^{-}$concentration and $\mathrm{pH}$. The data of effluent $\mathrm{F}^{-}$concentration and $\mathrm{pH}$ obtained in the above experiments are plotted in Fig. 4. It was found that the logarithm of effluent $\mathrm{F}^{-}$concentration was in direct proportion to effluent $\mathrm{pH}$ as shown in equation (12) and an effluent $\mathrm{F}^{-}$below $10 \mathrm{mg} \mathrm{l}^{-1}$ could be obtained at an effluent $\mathrm{pH}$ lower than 7.0. This result was consistent with those obtained by Ekdunge and Simonsson (1984), who found that $\mathrm{F}^{-}$ concentrations in effluents from a fixed bed reactor treating wastewater containing high concentration $\mathrm{NH}_{4} \mathrm{~F}$ were decreased by lowering $\mathrm{pH}$.

$$
\begin{gathered}
\mathrm{H}^{+}+\mathrm{CO}_{3}^{2-} \rightarrow \mathrm{HCO}_{3}^{-} \quad K=7.9 \times 10^{-11} \\
\mathrm{H}^{+}+\mathrm{HCO}_{3}^{-} \rightarrow \mathrm{H}_{2} \mathrm{CO}_{3} \quad K=4.6 \times 10^{-7} \\
\log _{10}\left[\mathrm{~F}^{-}\right]=0.51 \mathrm{pH}-2.91
\end{gathered}
$$

The above results demonstrated that the replacement reaction was actually controlled by $\left[\mathrm{H}^{+}\right]_{0} /$ $\left[\mathrm{F}^{-}\right]_{0}$. It is therefore theoretically possible to decrease effluent $\mathrm{F}^{-}$to any level by selecting a proper $\left[\mathrm{H}^{+}\right]_{0} /\left[\mathrm{F}^{-}\right]_{0}$. While it is difficult to measure $\left[\mathrm{H}^{+}\right]_{0} /\left[\mathrm{F}^{-}\right]_{0}$ in wastewater directly, the value of $\left[\mathrm{H}^{+}\right]_{0} /\left[\mathrm{F}^{-}\right]_{0}$ could be obtained indirectly through measuring effluent $\mathrm{Ca}^{2+}$ concentration, $\mathrm{F}^{-}$concentration or $\mathrm{pH}$. By feeding back the measured results to a controller to adjust acid or alkali feeding rate, it is possible to obtain a proper $\left[\mathrm{H}^{+}\right]_{0} /\left[\mathrm{F}^{-}\right]_{0}$. Therefore, a suitable process control strategy could be established on relationship between $\left[\mathrm{H}^{+}\right]_{0} /\left[\mathrm{F}^{-}\right]_{0}$ of wastewater and effluent $\mathrm{Ca}^{2+}$ concentration, $\mathrm{F}^{-}$ concentration or $\mathrm{pH}$. 


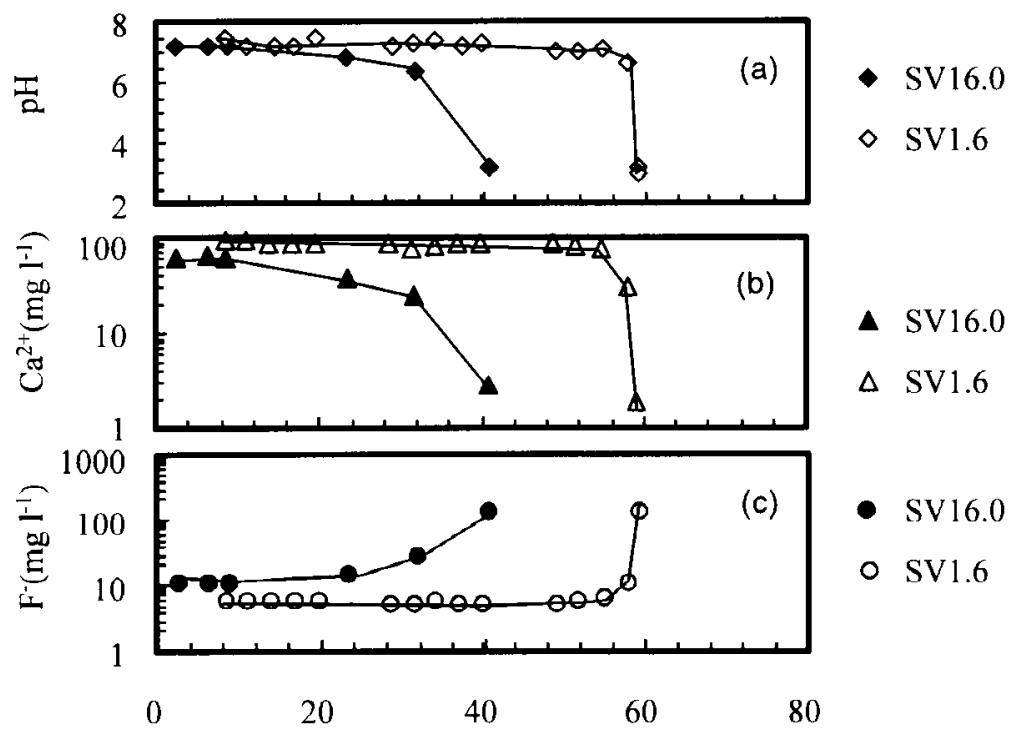

Calcite conversion rate $(\%)$

Fig. 5. (a), (b) and (c) Variations of effluent $\mathrm{pH}, \mathrm{Ca}^{2+}$ and $\mathrm{F}^{-}$with calcite conversion rate. Inf. $\mathrm{F}^{-}$, $300 \mathrm{mg} \mathrm{l}^{-1} ;\left[\mathrm{H}^{+}\right] /\left[\mathrm{F}^{-}\right], 0.75$.

\section{Operation conditions}

In a solid-liquid reaction system like the one used in this study, diffusion of dissolvable reactants and reaction products inside the particles becomes the rate limiting factor in many cases. So, the reaction time, i.e. HRT or SV, as well as particle size and reaction temperature is usually considered to be an important operation parameter. There have been several studies on the kinetics of calcite treatment processes (Simonsson, 1979; Sato, 1997). Just like other solid-liquid reactions, reducing particle size or raising temperature was found to be useful for improving $\mathrm{F}^{-}$removal efficiency. In order to evaluate the effects of reaction time, the SV was varied from 1.6 to $16.0 \mathrm{~h}^{-1}$ in steps. At each $\mathrm{SV}$, the treatment continued until breakpoint (which is defined as the point when the effluent $\mathrm{Ca}^{2+}$ decreased to below $5 \mathrm{mg}^{-1}$ in this study) was achieved. The $\left[\mathrm{H}^{+}\right]_{0} /\left[\mathrm{F}^{-}\right]_{0}$ of wastewater was adjusted to 0.75 to obtain an effluent $\mathrm{Ca}^{2+}$ concentration of ca. $80 \mathrm{mg} \mathrm{l}^{-1}$. Fig. 5(a), (b) and (c) show variations of effluent $\mathrm{F}^{-}, \mathrm{Ca}^{2+}$ and $\mathrm{pH}$, respectively, with calcite conversion rate, which is defined as the ratio of reacted $\mathrm{Ca}$ (the sum of $\mathrm{CaF}_{2}-\mathrm{Ca}$ and effluent $\mathrm{Ca}$ ) to the initial $\mathrm{CaCO}_{3}-\mathrm{Ca}$ in this study. It was found that effluent $\mathrm{pH}$ as well as both of the concentrations of effluent $\mathrm{F}^{-}$and $\mathrm{Ca}^{2+}$ was almost constant for a certain period at the first. Then sudden decreases of effluent $\mathrm{Ca}^{2+}$ and $\mathrm{pH}$ were observed with a significant increase of effluent $\mathrm{F}^{-}$. A high $\mathrm{SV}$ gave a high $\mathrm{F}^{-}$concentration and a low calcite conversion rate. The effluent $\mathrm{F}^{-}$is plotted against $\mathrm{Ca}^{2+}$ in logarithmic scale as shown in Fig. 6. It was found that the effluent $\mathrm{F}^{-}$was also linearly related with effluent $\mathrm{Ca}^{2+}$ logarithmically and the relation was almost not affected by the difference of SV (from 1.6 to $16.0 \mathrm{~h}^{-1}$ ). The plot in Fig. 3 was also inserted in Fig. 6 for comparison and its slope was found to be smaller than that obtained here. The data from Fig. 3 were obtained before breakpoint was reached, while data from Fig. 5 were obtained through the whole treatment. So, it seemed that the relation between effluent $\mathrm{Ca}^{2+}$ concentration and effluent $\mathrm{F}^{-}$concentration changed a little after the fixed bed reached breakpoint. The reason for this difference is not clear.

Figure 7 shows the relation between SV and calcite conversion ratio. The calcite conversion ratio was almost linearly related with the SV at an SV over $3.0 \mathrm{~h}^{-1}$. During treatment, some lumps as large as 0.5 to $2 \mathrm{~cm}$ in diameter were found after the spent calcite particles were pulled out from the reactor. Since both the amount of calcite and the initial $\mathrm{F}^{-}$concentration were constant, the treat-

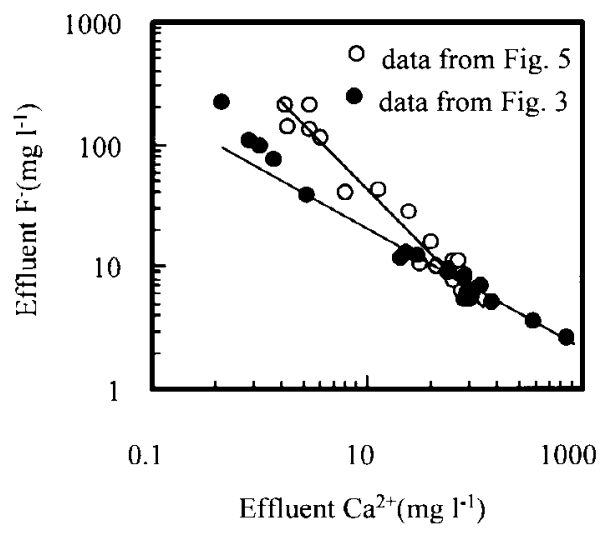

Fig. 6. Relations between effluent $\mathrm{Ca}^{2+}$ and $\mathrm{F}^{-}$. 


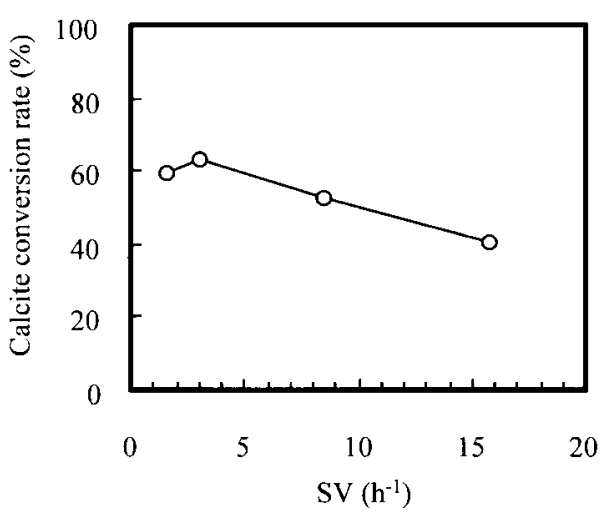

Fig. 7. Effect of SV on calcite conversion rate. For conditions, see Fig. 5.

ment cycle became longer and the upflow linear velocity (LV) decreased with the decrease of SV, which made it easy to form lumps at a lower SV. The irregularity of conversion ratio at $\mathrm{SV} 2 \mathrm{~h}^{-1}$ was perhaps originated from formation of lumps since the treatment lasted for as long as more than 1 month. It was apparent that a low SV was desirable from the viewpoint of effective utilization of calcite. However, some measures are necessary for preventing formation of lumps in the reactor. On the other hand, more efforts should be made to increase the effective utilization rate of calcite since the highest conversion ratio was about $60 \%$ under the above conditions.

Another important factor possibly affecting $\mathrm{F}^{-}$ removal efficiency is reaction temperature. Simonsson (1979) considered the calcite replacement reaction at room temperature being too slow to be of practical use. However, the results in our study demonstrated that the process could be put into practical use even at a temperature of $25^{\circ} \mathrm{C}$ if a proper $\left[\mathrm{H}^{+}\right]_{0} /\left[\mathrm{F}^{-}\right]_{0}$ ratio and $\mathrm{SV}$ were selected. In order to investigate performance of the fixed-bed at lower temperatures, $\mathrm{F}^{-}$removal at 16.5 and $8.5^{\circ} \mathrm{C}$ were also conducted, respectively (Fig. 8). The reactor was operated at the following conditions: $\left[\mathrm{H}^{+}\right]_{0} /$ $\left[\mathrm{F}^{-}\right]_{0}$ ratio, 0.75 ; influent $\mathrm{F}^{-}, 300 \mathrm{mg}^{-1} ; \mathrm{SV}$, $7.0 \mathrm{~h}^{-1}$. It is clear that while the difference between 25.0 and $16.5^{\circ} \mathrm{C}$ was not so significant, the $\mathrm{F}^{-}$ removal efficiency decreased drastically when the temperature was decreased to $8.5^{\circ} \mathrm{C}$. At $8.5^{\circ} \mathrm{C}$, not only an early breakpoint, but also a significantly increased effluent $\mathrm{F}^{-}$was observed.

\section{Effects of co-existing ions}

In the calcite treatment process, $\mathrm{F}^{-}$is removed through the formation of $\mathrm{CaF}_{2}$. So, anions like $\mathrm{SO}_{4}^{2-}$ and $\mathrm{PO}_{4}^{3-}$ are possible to have some effects on $\mathrm{F}^{-}$removal performance since they can react with $\mathrm{Ca}^{2+}$ to form precipitates of $\mathrm{CaSO}_{4}$ and $\mathrm{CaHPO}_{4}$ (or $\mathrm{Ca}_{3}\left(\mathrm{PO}_{4}\right)_{2}$, according to reaction $\mathrm{pH}$ ), respectively. The effects of $\mathrm{SO}_{4}^{2-}$ (added as $\mathrm{Na}_{2} \mathrm{SO}_{4}$ ) and $\mathrm{PO}_{4}^{3-}$ (added as $\mathrm{Na}_{2} \mathrm{HPO}_{4}$ ) were investigated, respectively, at an $\left[\mathrm{H}^{+}\right]_{0} /\left[\mathrm{F}^{-}\right]_{0}$ ratio of 0.75 . The other conditions are shown in respective figures. Fig. 9(a) shows that the effluent $\mathrm{F}^{-}$concentrations increased with the increase of $\mathrm{SO}_{4}^{2-}$ concentration. The existence of $300 \mathrm{mg} \mathrm{l}^{-1} \mathrm{SO}_{4}^{2-}$ gave an increase of $\mathrm{F}^{-}$concentration by $50 \%$. When $2.6 \mathrm{mg} \mathrm{l}^{-1} \mathrm{PO}_{4}^{3}$ coexisted with $\mathrm{SO}_{4}^{2-}$, effluent $\mathrm{F}^{-}$concentration increased more significantly. It was found that the inhibiting effect of $\mathrm{PO}_{4}^{3-}$ was more profound than that of $\mathrm{SO}_{4}^{2-}$ as shown in Fig. 9(b). Addition of $29 \mathrm{mg} \mathrm{l}^{-1} \mathrm{PO}_{4}^{3-}$ resulted in an increase of effluent $\mathrm{F}^{-}$concentration from $6 \mathrm{mg} \mathrm{l}^{-1}$ to more than $30 \mathrm{mg}^{-1}$. So, the existence of an even relatively low concentration of $\mathrm{PO}_{4}^{3-}$ would make it difficult to employ the calcite process to treat $\mathrm{F}^{-}$-bearing wastewater.

During treatment, ca. $9 \%$ of initial $\mathrm{SO}_{4}^{2-}$ was removed from wastewater while $\mathrm{PO}_{4}^{3-}$ was reduced to a level unable to be detected on ion-chromatograph. The solubility products of $\mathrm{CaSO}_{4}$ and $\mathrm{CaHPO}_{4}\left(\mathrm{CaHPO}_{4}\right.$ should be the dominating specie at an effluent $\mathrm{pH}$ of 6.8 ) are $1.2 \times 10^{-6}$ to $2.27 \times$

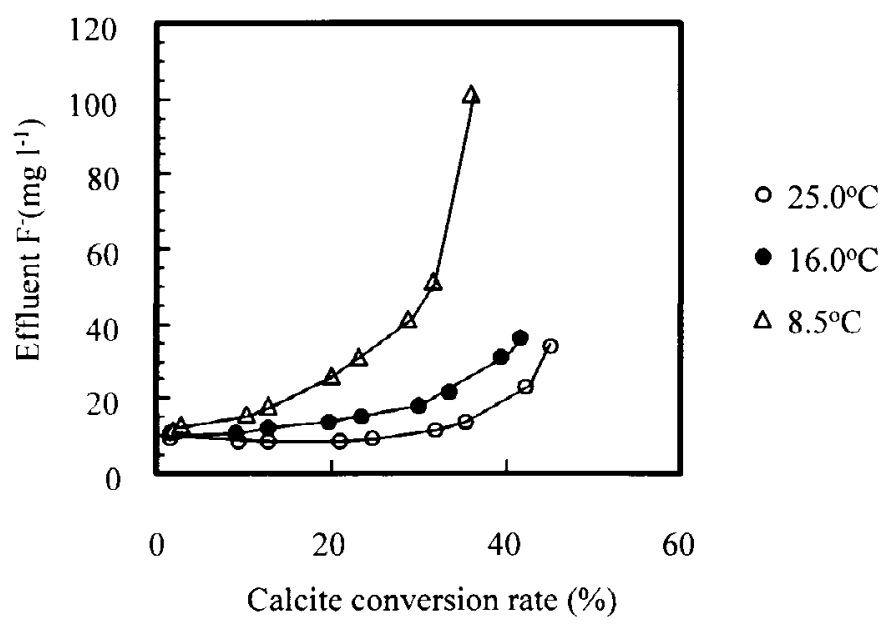

Fig. 8. Effect of temperature on $\mathrm{F}^{-}$removal. SV, $7 \mathrm{~h}^{-1}$; Inf. $\mathrm{F}^{-}, 300 \mathrm{mg}^{-1} ;\left[\mathrm{H}^{+}\right] /\left[\mathrm{F}^{+}\right], 0.75$. 

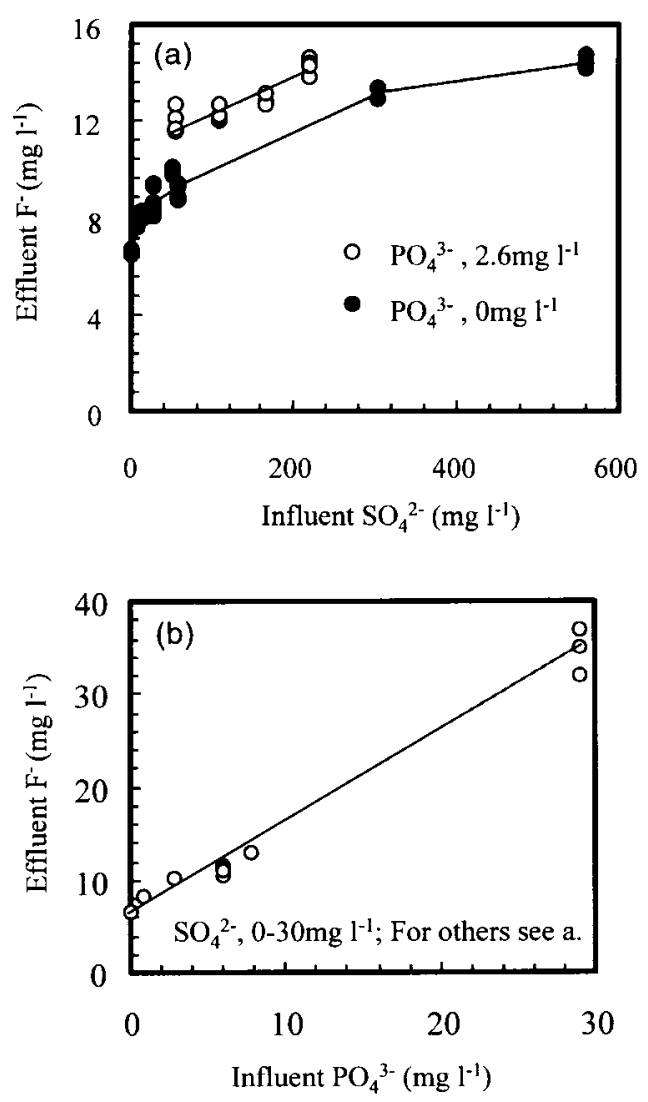

Fig. 9. (a) Effects of $\mathrm{SO}_{4}^{2-}$ and $\mathrm{PO}_{4}^{3-}$ on $\mathrm{F}^{-}$removal. $\mathrm{SV}$, $6 \mathrm{~h}^{-1}$; Inf. $\mathrm{F}^{-}, 300 \mathrm{mg} \mathrm{l}^{-1} ;\left[\mathrm{H}^{+}\right] /\left[\mathrm{F}^{-}\right], 0.75$ (not including $\mathrm{H}^{+}$from $\mathrm{NaH}_{2} \mathrm{PO}_{4}$ ). (b) Effects of $\mathrm{SO}_{4}^{2-}$ and $\mathrm{PO}_{4}^{3-}$ on $\mathrm{F}^{-}$ removal.

$10^{-5}$ and $1 \times 10^{-7}$ to $2.55 \times 10^{-7}$ (Japan Society on Chemistry, 1975), respectively, considerably higher than that of $\mathrm{CaF}_{2}\left(3.45 \times 10^{-11}\right)$. It is interesting that the ions of $\mathrm{SO}_{4}^{2-}$ and $\mathrm{PO}_{4}^{3-}$ were removed even when the ion products were below the respective solubility product of $\mathrm{CaSO}_{4}$ and $\mathrm{CaHPO}_{4}$. It is clear that inhibition of $\mathrm{SO}_{4}^{2-}$ and $\mathrm{PO}_{4}^{3-}$ on $\mathrm{F}^{-}$ removal was not caused by competition for $\mathrm{Ca}^{2+}$ since the effluent $\mathrm{Ca}^{2+}$ was relatively constant, being 70 to $80 \mathrm{mg} \mathrm{l}^{-1}$ through each run.

In order to investigate inhibition of $\mathrm{PO}_{4}^{3-}$ on $\mathrm{F}^{-}$ removal further, influent $\mathrm{F}^{-}$concentration was increased stepwise from 5 to $300 \mathrm{mg} \mathrm{l}^{-1}$ while $\mathrm{PO}_{4}^{3-}$ was kept constant at $15 \mathrm{mg}^{-1}$. $\mathrm{NaF}$ was used as the $\mathrm{F}$ source, and the effluent $\mathrm{Ca}^{2+}$ concentration was adjusted to around $80 \mathrm{mg}^{-1}$ by adding $\mathrm{HCl}$ to synthetic wastewater. The results are shown in Fig. 10. It was found that removal of $\mathrm{F}^{-}$did not occur until the molar ratio of $\mathrm{PO}_{4}^{3-}$ to $\mathrm{F}^{-}$was decreased to 0.05 (at initial $\mathrm{F}^{-}$concentration of $50 \mathrm{mg} \mathrm{l}^{-1}$ ). Although a slight scattering of data was observed, the $C / C_{0}$ of $\mathrm{PO}_{4}^{3-}$ varied in a narrow range between 53 and $60 \%$ at a $\mathrm{PO}_{4}^{3-}$ to $\mathrm{F}^{-}$ratio larger than 0.05 except for one point. The relatively constant $\mathrm{PO}_{4}^{3-}$ removal was perhaps because the effluent $\mathrm{Ca}^{2+}$ was almost kept at a constant level. $\mathrm{F}^{-}$removal began

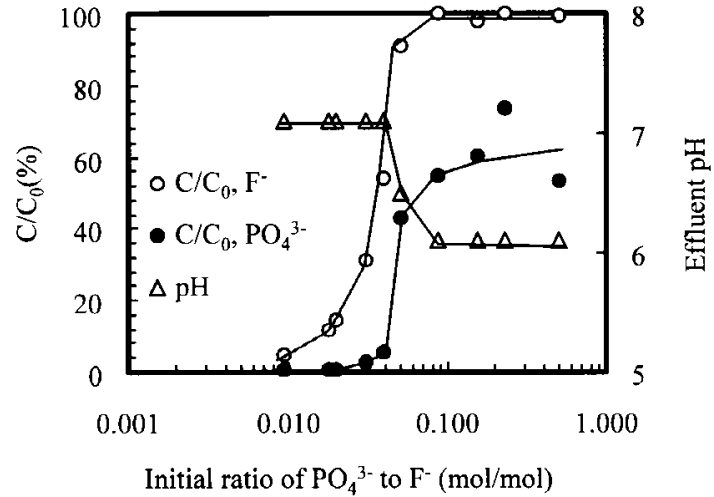

Fig. 10. Effects of $\mathrm{PO}_{4}^{3-}$ to $\mathrm{F}^{-}$ratio on $\mathrm{PO}_{4}^{3-}$ and $\mathrm{F}^{-}$ removal. $\mathrm{SV}, 6 \mathrm{~h}^{-1}$; Inf. $\mathrm{PO}_{4}^{3-}, 15 \mathrm{mg} \mathrm{l}^{-1}$.

to be observed when the $\mathrm{PO}_{4}^{3-} / \mathrm{F}^{-}$ratio was reduced to 0.05 and improved significantly with the decrease of ratio. It is interesting that $\mathrm{PO}_{4}^{3-}$ removal also increased significantly at the same time. While the existence of $\mathrm{PO}_{4}^{3-}$ markedly inhibited $\mathrm{F}^{-}$removal, the existence of certain amount of $\mathrm{F}^{-}$seemed to be necessary for achieving complete $\mathrm{PO}_{4}^{3-}$ removal. It was possible that some $\mathrm{PO}_{4}^{3-}$ might be included by $\mathrm{CaF}_{2}$ to form an $\mathrm{F}^{-}-\mathrm{PO}_{4}^{3-}-$ $\mathrm{Ca}^{2+}$ complex when $\mathrm{F}^{-}$was removed. Figure 10 demonstrates that the dominated reaction changed with the variation of $\mathrm{PO}_{4}^{3-} / \mathrm{F}^{-}$ratio: formation of $\mathrm{CaHPO}_{4}$ dominated at a $\mathrm{PO}_{4}^{3-} / \mathrm{F}^{-}$ratio higher than 0.05 , and formation of $\mathrm{CaF}_{2}$ began to dominate at a $\mathrm{PO}_{4}^{3-} / \mathrm{F}^{-}$ratio lower than 0.05 . Variation of effluent $\mathrm{pH}$ also supported the above observation. It is interesting that although the solubility product of $\mathrm{CaF}_{2}$ was much lower than that of $\mathrm{CaHPO}_{4}$. the molar concentration of $\mathrm{F}^{-}$had to be more than 20 times higher than that of $\mathrm{PO}_{4}^{3-}$ in order to initiate $\mathrm{F}^{-}$removal. It is possible that $\mathrm{CaHPO}_{4}$ grains formed on the surface of calcite particles had prevented $\mathrm{CaF}_{2}$ seeds from forming when $\mathrm{F}^{-}$was insufficient.

\section{CONCLUSION}

A fixed bed reactor filled with calcite particles was constructed, and the reactor was used to treat synthetic wastewater containing $\mathrm{HF}, \mathrm{NaF}, \mathrm{NH}_{4} \mathrm{~F}$ or $\mathrm{Na}_{2} \mathrm{SiF}_{6}$ under various conditions. The molar ratio of $\mathrm{H}^{+}$to $\mathrm{F}^{-}$in wastewater was varied to investigate its effects on dissolution of $\mathrm{Ca}^{2+}$ and the study was focused on elucidating relations among effluent $\mathrm{F}^{-}, \mathrm{Ca}^{2+}$ and $\mathrm{pH}\left(\mathrm{H}^{+}\right)$in order to establish a process control strategy. The effects of SV, temperature and coexisting ions on $\mathrm{F}^{-}$removal were also investigated. The results are summarized as follows:

1. $\mathrm{Ca}^{2+}$ was found to exist in the treated effluent and the molar $\mathrm{Ca}^{2+}$ concentration $\left(\left[\mathrm{Ca}^{2+}\right]\right)$ was related to the initial ratio of $\mathrm{H}^{+}$to $\mathrm{F}^{-}\left(\left[\mathrm{H}^{+}\right]_{0} /\right.$ 
$\left.\left[\mathrm{F}^{-}\right]_{0}\right)$ as $\log _{10}\left[\mathrm{Ca}^{2+}\right]=0.020\left[\mathrm{H}^{+}\right]_{0} /\left[\mathrm{F}^{-}\right]_{0}-4.24$.

2. The effluent $\mathrm{F}^{-}$concentration was found to be determined by the concentration of effluent $\mathrm{Ca}^{2+}$ as $\left[\mathrm{F}^{-}\right]^{2}\left[\mathrm{Ca}^{2+}\right]^{0.94}=3.98 \times 10^{-10}$ under an $\mathrm{SV}$ of 1.0 to $5.0 \mathrm{~h}^{-1}$. This relation could be applied to wastewaters containing $\mathrm{HF}, \mathrm{NaF}, \mathrm{NH}_{4} \mathrm{~F}$ or $\mathrm{Na}_{2} \mathrm{SiF}_{6}$ and was not affected by variations of influent $\mathrm{F}^{-}$concentration from 25 to $3000 \mathrm{mg} \mathrm{l}^{-1}$.

3. The effluent $\mathrm{F}^{-}$was also found to be related to effluent $\mathrm{pH}$ as $\log _{10}\left[\mathrm{~F}^{-}\right]=0.51 \mathrm{pH}-2.91$, and the effluent $\mathrm{F}^{-}$was about $6 \mathrm{mg} \mathrm{l}^{-1}$ at an effluent $\mathrm{pH}$ of 6.8 .

4. The effluent $\mathrm{F}^{-}$increased from 6 to $12 \mathrm{mg}^{-1}$ and effective calcite conversion rate decreased from $c a$. 60 to $40 \%$ when SV was increased from 1.6 to $16.0 \mathrm{~h}^{-1}$ at an $\left[\mathrm{H}^{+}\right]_{0} /\left[\mathrm{F}^{-}\right]_{0}$ of 0.75 .

5. Significant increase of effluent $\mathrm{F}^{-}$as well as decrease of effective calcite conversion rate was observed when reaction temperature was decreased from 25.0 to $8.5^{\circ} \mathrm{C}$.

6. The performance of the reactor was affected by the existence of $\mathrm{SO}_{4}^{2-}$ to some extent and significantly inhibited by $\mathrm{PO}_{4}^{3-}$. A molar ratio of $\mathrm{PO}_{4}^{3-}$ to $\mathrm{F}^{-}$higher than 0.05 stopped $\mathrm{F}^{-}$removal at a $\mathrm{PO}_{4}^{3-}$ of $15 \mathrm{mg} \mathrm{l}^{-1}$.

7. Efforts should be made to increase the effective conversion rate of calcite and prevent formation of lumps in the fixed bed.

\section{REFERENCES}

Augustyn W., Dzieegielewska A., Kossuth A. and Librant Z. (1978) Studies of the reaction of crystalline calcium carbonate with aqueous solutions of $\mathrm{NH}_{4} \mathrm{~F}, \mathrm{KF}$ and NaF. J. Fluorine Chem. 12, 281-292.
Cordell G. B. (1968) Reaction kinetics of the production of ammonium sulfate from anhydrite. I\&EC Process Design and Development 7, 278-285.

Ekdunge P. and Simonsson D. (1984) Treatment of ammonium fluoride solutions in a semicontinuous fixed bed process. J. Chem. Tech. Biotechnol. 34A, 1-9.

Eto Y. and Takadoi T. (1978) Advanced treatment method of $\mathrm{F}^{-}$-bearing wastewater. J. Water Waste 20(6), 667-674.

Glover E. D. and Sippel R. F. (1962) Experimental pseudomorphs: replacement of calcite by fluorite. $\mathrm{Am}$. Mineralog. 47(9-10), 1156-1165.

Japan Society on Chemistry (1975) Chemical Handbook; Fundamentals, 2nd ed. Maruzen, Tokyo.

Majima T. and Takatsuki H. (1987) Fluoride removal from smoke-washing wastewater by using $\mathrm{CaF}_{2}$ separating method. Water Purification Liquid Wastes Treatment 28(7), 433-443.

Mooney G. A., Nogueira A. T. and Cope D. C. (1982) Two-stage lime treatment in practice. Environ. Prog. 1(4), 274-280.

Miki N., Maeno M., Fukudome T. and Ohmi T. (1996) Advanced fluorine regeneration technology to recover spent fluoride chemicals drained from semiconductor manufacturing process. IEICE Trans. Electron. E79C(3), 363-374.

Ohmi T. (1995) Process Innovation established on Fluorine Chemistry. Realize, Tokyo, p. 35

Sato S., Hitotsuyanagi N. and Yabe K. (1995) Practical application of fluoride recovery and processing technology to existing waste water treatment systems. In Proceedings of Conference on Semiconductor Pure Water and Chemicals, pp. 391-396.

Sato S. (1997) A fluoride regeneration technology from wastewater by using granular calcium carbonate. J. Soc. Water Environ. 20(6), 391-396.

Simonsson D. (1979) Reduction of fluoride by reaction with limestone particles in a fixed bed. Ind. Eng. Chem. Process Des. Dev. 18(2), 288-292.

Trautz O. R. and Zaparta R. R. (1961) Experiments with calcium carbonate phosphates and the effect of topical application of sodium fluoride. Arch Oral Biol. Special Supplement 4, 122-133. 